\title{
Rotary querns and millstones in South-West England
}

\author{
Susan Watts and Martin Watts
}

\begin{abstract}
The south-west of England comprises some of the most varied geology in the British Isles. This has not only given rise to a diverse landscape but has also provided the region with various sources of stone suitable for the production of milling stones. Analysis of the different types of stone that were used for the manufacture of rotary querns and millstones in the south-west of England shows two main trends. Firstly, a preference, whether by necessity or desirability, for locally sourced stones. Secondly, the introduction of and, despite their higher cost, the increased importation of French millstones from the medieval period onwards. This is coupled with an increasing use of stones of Millstone Grit from northern England in the 18th and 19th centuries. It was the importation of these millstones that was to lead ultimately to the demise of the local millstone making industries.
\end{abstract}

Keywords: quern, millstone, south-west England, Devon, Cornwall, Somerset, granite, Old Red Sandstone, French burr, millstone grit

Susan Watts, Devon County Council, County Hall, Topsham Road, Exeter, Devon, email:susan.watts@devon.gov.uk

Martin Watts, Honorary Associate Research Fellow, College of Humanities, University of Exeter, email:M.Watts@exeter.ac.uk

\section{Introduction}

Topographically the south-west of England is a region of contrasts. This is primarily due to the underlying geology which varies considerably from east to west (Fig. 1). Along the eastern border of the region are Jurassic limestones; Blue Lias limestone underlies the Somerset Levels and caps the Polden Hills. The Mendip Hills comprise Devonian Old Red Sandstone surrounded by Carboniferous limestone. Coal Measures are found in the Bristol region and Triassic marls and sandstones in the Vale of Taunton. There is Cretaceous clay and Upper Greensand in the Blackdown Hills of southwest Somerset and east Devon, and Permian New Red Sandstone and breccia in the Exeter area.
Large areas of west Devon and north-east Cornwall comprise Culm Measures of the Carboniferous period, while Devonian sandstones underlie south Devon and Cornwall. Exmoor is also comprised of Devonian slates and sandstones. Dominating the western half of the region, in Devon and Cornwall, are the large granite bosses of Dartmoor, Bodmin Moor, Hensbarrow, Carnmenellis, West Penwith and the Isles of Scilly (Ordnance Survey 1957; Hesketh 2008; Natural England 2009). This varied geology has given rise to a corresponding diverse landscape of rolling hills, the low lying Somerset levels, deep wooded river valleys, rocky headlands and high moorlands. It has also provided the region with a variety of rock types suitable for the production of rotary querns and millstones. 


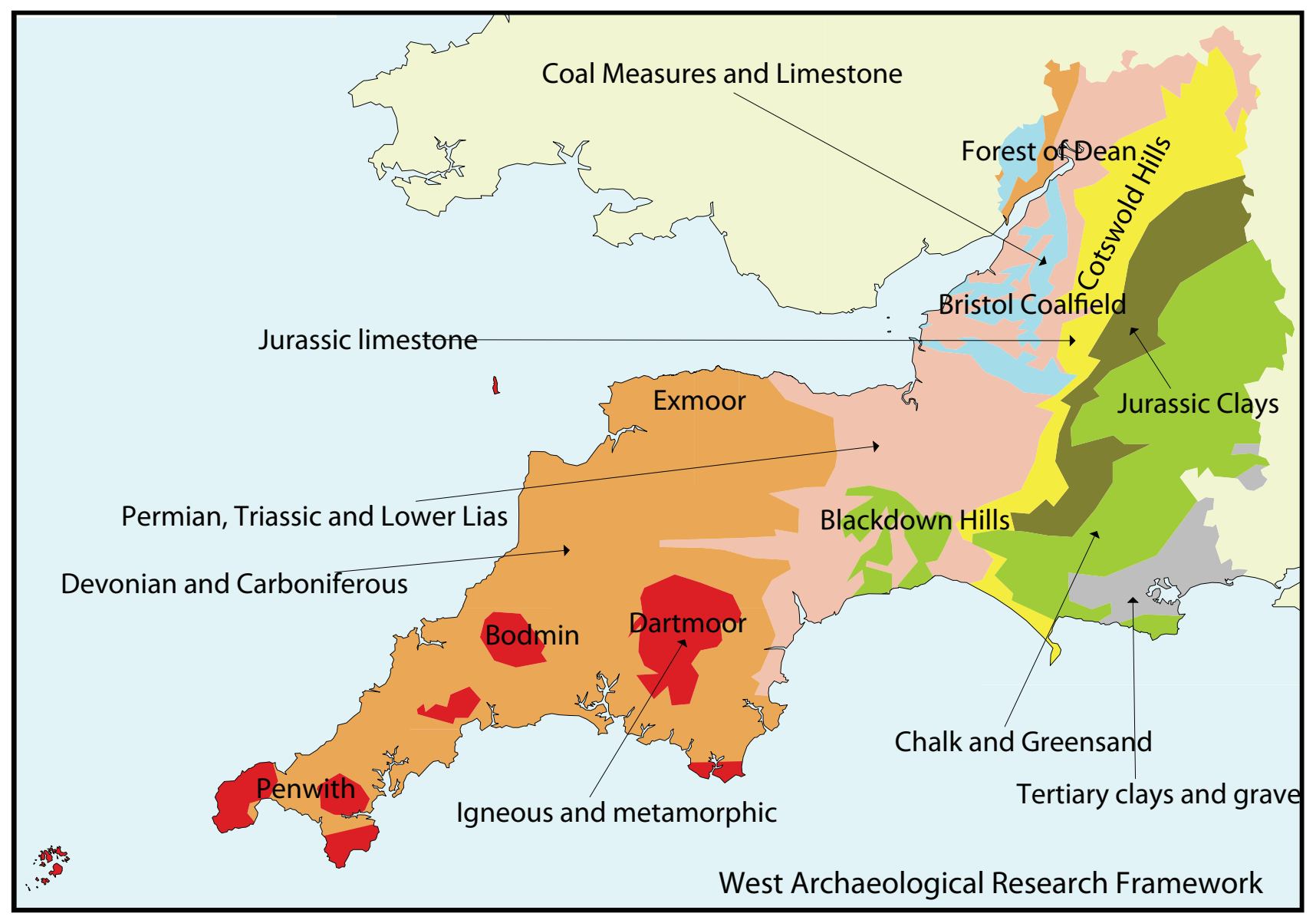

Fig. 1: Simplified geological map of south-west England (South West Archaeological Research Framework, courtesy of Chris Webster).

The principal function of querns and millstones is to grind a raw material, be that vegetable, mineral or animal, into a usable product. This is achieved not simply by crushing the raw material but by shearing it with a scissor-like cutting action. As Buckman $(1866,291)$ commented: 'the primary requisite in a millstone is, that it should be made up of hard cutting particles'. The best types of rock for making querns and millstones, therefore, are those with a well-cemented matrix of fine to medium grains which give a naturally hard-wearing and abrasive surface, or a vesicular texture which provides continuous cutting edges even as it wears (Watts 2014, 29). A wide variety of rock types have been used over the millennia to produce milling stones, including sedimentary rocks such as sandstones and limestones, igneous basalts and granites and, less frequently, some metamorphic rocks. Indeed, as Peacock (1980, 43) comments, 'almost any suitable outcrop would be quarried to meet local demand'. But as Buckman (1866, 291) said: 'when stones suitable [for milling]...were not to be found on the spot, they had to be obtained from various distances, according to circumstances'.

This paper, which is based on presentations given by the authors at the Millstone Colloquiums in Bergen, Norway in 2011 and Almeria, Spain in 2014, looks at the different types of stone that were used for the production of the rotary querns and millstones found in the south-western counties of England from the Iron Age and Roman periods through to the 20th century. The aim of the paper is to provide an overview of the different rock types that were used rather than giving detailed petrographic descriptions Few quarry sites have been identified in the south-west and dedicated fieldwork has not been undertaken. Some additional information, however, is given in the endnotes. Utilising both documentary sources and surviving querns and millstones, the focus is on stones that were used for grinding cereals. For the purposes of this paper, south-west England is defined as Devon and Cornwall and the historic county of Somerset. 


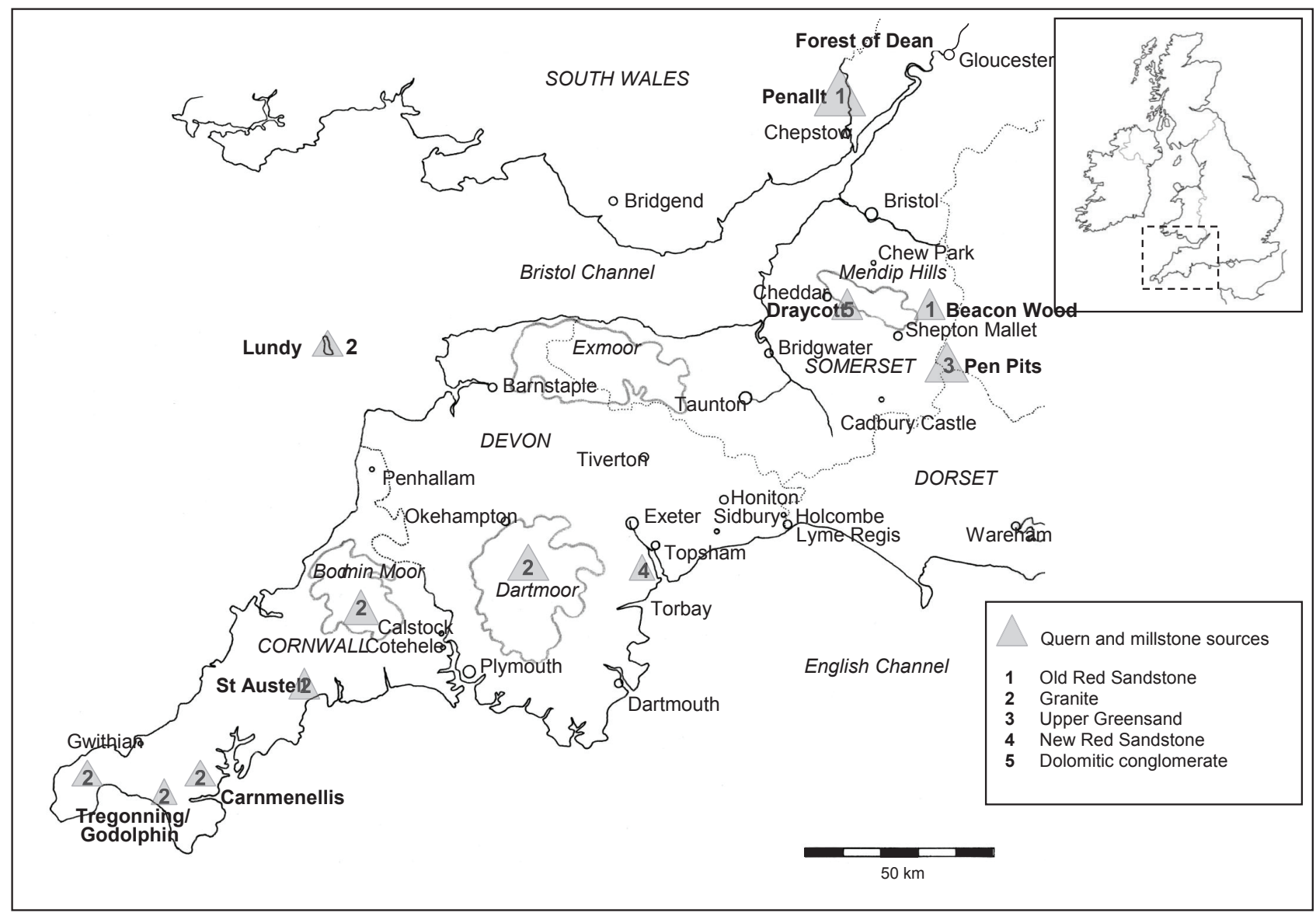

Fig. 2: Map showing the principal places and quarries mentioned in the text.

\section{Previous work on the sources of querns and millstones in south-west England}

The majority of studies of milling stones have tended to concentrate on a particular type or source of stone, or on a specific period and, while some focus on the quarries from whence querns and millstones came, others discuss the finished product. The majority of reports are comparatively recent, dating from the 1970s and 1980s or later, but there are several much earlier papers of interest and import. One of the earliest that mentions querns and millstones from sources in the south-west is by Buckman $(1866,293)$, who refers to unfinished stones of Old Red Sandstone quartz conglomerate ${ }^{1}$ found in the Forest of Dean in Gloucestershire and Upper Greensand ${ }^{2}$ from

1. The texture and appearance of Devonian Old Red Sandstone varies considerably from fine to coarse grained and grey-brown to red in colour. A variety of Old Red Sandstone found in the Forest of Dean, Gloucestershire, Penallt in South Wales and in the Mendips is a quartz conglomerate containing varying amounts of quartz pebbles, often stained pink. Sometimes the pebbles are so few that the stone appears in effect to be a plain sandstone (Tucker 1971, 229, 232; Shaffrey 2006, 5-13, 21, 23, 24).

2. Upper Greensand contains grains of glauconite which give the stone it its characteristic greenish colour.
Pen Pits on the Somerset-Dorset-Wiltshire border (Fig. 2). Pitt-Rivers (1884) discusses the theories proposed for the function of Pen Pits, proving by excavation that they were indeed quarry pits and not pit dwellings. Crawford (1953, 100-102) also discusses Pen Pits. Tucker (1971) looks at millstone making at Penallt, Monmouthshire while Peacock $(1980,43)$ notes that quartz conglomerate from the Forest of Dean was amongst the sources in Britain exploited during the Roman period. Kempe and Harvey (1983) likewise identify the Forest of Dean as a major source of milling stones and they also list Draycott in Somerset as a source of a Triassic Dolomitic conglomerate. Ingle (1984) and Barford (1984) explore the petrology of querns and quern quarries in the Bristol region, while Mullin (1988) searches for quarry locations in the Forest of Dean. More recently Shaffrey (2006) has produced a comprehensive study of querns and millstones of Old Red Sandstone in the Roman period. At the other end of the production line, Farmer (1992) explores where medieval manors, including some estates in Somerset, obtained their millstones. By comparison there have been very few articles pertaining to millstone production in Devon and Cornwall, the short papers by Robinson (1981) and Fox (1994) being notable exceptions. However, in addition to these studies, many archaeological reports on querns and millstones from individual 


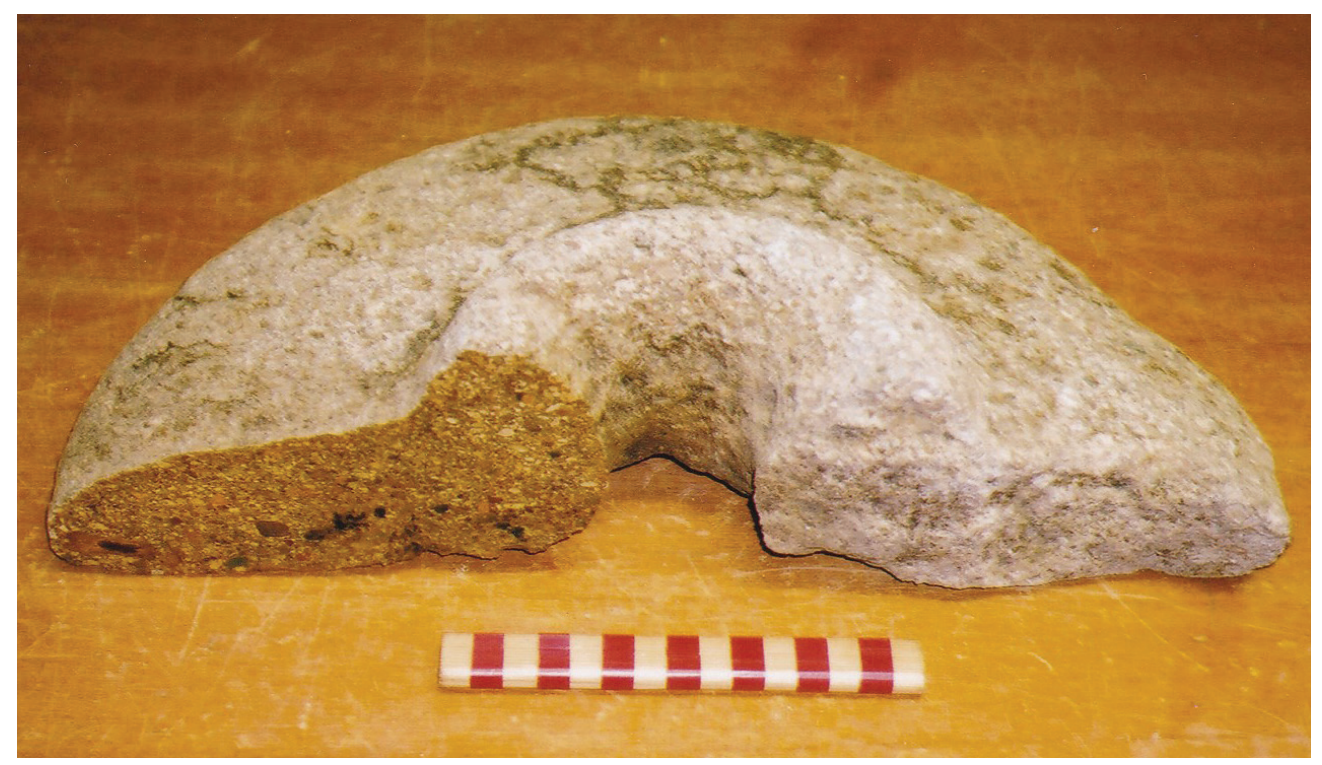

Fig. 3: Conglomerate rotary quern from Trethurgy, Cornwall.

sites contain analyses of their origins which can be used to build up a 'supply map'. This paper, then, is rather different from what has been previously written in that it does not focus on a particular period or a particular site or quarry but presents a summary of the different types of stone that were used for the production of rotary querns and millstones, beginning with the Iron Age and Roman periods.

\section{The Iron Age and Roman Periods, 700 BC-AD 410}

In common with the rest of the British Isles, rotary querns were first used in the south-west of England during the Iron Age. However, those Iron Age sites in the region that have produced rotary querns indicate that their earliest use was somewhat later than the 4th century BC which is generally suggested for their introduction into Britain. The earliest deposits containing querns at Cadbury Castle in Somerset appear to date from the 3rd century BC and further west, in Cornwall in particular, rotary querns do not seem to have been used until the 2 nd century BC at the earliest (Watts 2014, 103). By the Roman period, however, they were in common use across the region. A rapid survey of rotary querns recorded in published and grey literature reports for 67 Iron Age and Romano-British sites (23, 24 and 20 from Cornwall, Devon and Somerset respectively), indicates that the majority were sourced reasonably locally, up to about $25 \mathrm{~km}$, from where they were found. Consequently a gradual shift can be seen from granite, greisen and elvan ${ }^{3}$ in Cornwall, south-

3. Greisen results from the alteration of granite during the final stages of cooling during which feldspar was replaced by quartz and mica. It is softer than granite and finer grained (Quinnell 1993, 31). Elvan, the local name for quartz porphyry, occurs in dykes around the granite areas of Cornwall (Quinnell 1993, 31, fig. 1) west Devon and Dartmoor to Permian sandstone, lava and breccia in the Exeter area, to Hangman and Foreland Grits in north Devon and Exmoor, to limestone, Old Red Sandstone and Upper Greensand in Somerset. There are, of course, exceptions to the rule, as the following example illustrates.

Fragments from nine upper and three lower rotary quernstones were found during excavations at Trethurgy Round near St. Austell, Cornwall, a small enclosure occupied from the mid 2nd to the 6 th century AD. All but two of the stones are of very locally sourced elvan. One of the other two fragments, from an upper stone recovered from a late-4th century midden, is of greisen, either from the St. Austell granite, again very local, or possibly from the Tregonning granite, about $50 \mathrm{~km}$ to the south-west. The final fragment, from a quern that had been broken by the early 4th century, comes from much further afield, being one of the few imported querns found in the county (Fig. 3). It is of a conglomerate thought to derive from the Pennant Sandstone formation which overlies the South Wales Coal Measures ${ }^{4}$ (Quinnell and Watts 2004, 145-51). On present evidence it must be considered an atypical stone for a Cornish site (although see below) and potentially signifies a particular relationship or contact between the two areas, although of course its presence could be the result of a much shorter exchange within a broader trading network.

In addition, research by Shaffrey (2004) has shown that although many Roman sites in Somerset acquired querns of Old Red Sandstone, particularly quartz conglomerate from local sources in the Portishead/Bristol area and from the Mendip Hills, some also obtained them from quarries on both

4. The Coal Measures extend both sides of the river Severn, being found in South Wales and in the Bristol Area (Fig. 1). 
sides of the lower valley of the river Wye, which forms the border between England and Wales, from the Forest of Dean on the Gloucestershire side but more particularly from the Penallt area, on the Monmouthshire side.

Shaffrey suggests that the availability of other natural resources in the area, such as iron ore, coupled with the ease of transport which the river provided, made it a prime area for quernstone production. The quernstones are likely to have been transported down the Wye to the river Severn which would have given ready access to Bristol and down the Bristol Channel to Somerset (Shaffrey 2004, 2021). Shaffrey (2004, fig. 3.2) has recorded querns of Penallt Old Red Sandstone conglomerate on seven sites in Somerset, the furthest west being a surface find from Cheddon Fitzpaine, near Taunton. None were recorded from Devon or Cornwall. No evidence of Roman quarries has been found, however, later workings probably having destroyed the earlier ones.

No quarries of Iron Age or Roman date have been identified as yet in Devon and Cornwall either. It is likely that, as in later times, surface boulders were utilised, leaving little or no evidence. Several quarries have, however, been located in Somerset. Workings comprising shallow pits, adits and open quarry faces in Beacon Wood to the north of Shepton Mallet, for example, appear to be the source of a conglomeritic Old Red Sandstone that was used for querns found during excavations at sites including Shepton Mallet, Camerton, Ilchester, Cadbury Castle and also Glastonbury, all in Somerset. Beacon Wood is located on the Fosse Way, an important Roman road, and appears to have supplied a locally extensive area (Somerset HER No. 15485, Roe 2000, 263-4; Roe 2001, 235; Roe 1995, 165).

Another significant quarry area is the Pen Pits, near the villages of Zeals and Penselwood, on the borders of Somerset, Wiltshire and Dorset (Fig. 4). The Upper Greensand not only outcrops here but also all along the escarpment to the north. However, it is considered that the main quarry site was chosen as it was close to a major routeway (now the A303) which provided ease of transport both to the west and eastwards into Wiltshire (Crawford 1953, 100). The pits cover an area of some 283 hectares and appear to be multi-period, dating back to the Iron Age. Querns from Pen Pits have been found, for example, at Cadbury Castle and Shepton Mallet (Somerset HER No. 54382; Roe 2000, 264; Roe 2001, 235). Today most of the pits are infilled and the earthworks formed by upcast from them levelled by ploughing, although a small area still survives to the south-east of Zeals (Rawlings 1995, 42-4).

Moving much further afield, there is some evidence for the importation of lava querns into the region from Mayen in the Eifel Hills in Germany. Fragments of these have been found in association with the Roman forts at Exeter and Pomeroy Wood, near Honiton in Devon and Calstock in Cornwall (Bell and Bradshaw 1983; Loader 1999, 281). An unstratified fragment found at Sea Mills near Bristol may also have derived from the 1st century AD military occupation of the site (Ellis 1989, 68). The larger fragments of upper stones from Calstock and Exeter show them to be typical of lava querns of the early Roman period, with a kerb around the upper circumference and an L-shaped handle hole through the side. The fragment from Sea Mills likewise had a kerb.

Power-driven mills for processing cereal crops were introduced into Britain during the 1st century $\mathrm{AD}$ and some 200 millstones have been identified in association with a variety of rural, urban and military sites throughout Britain (King 1998). The majority of these are presumed to have been used in watermills, although only a small number of sites have been identified in Britain and none in the south-west. The Roman millstones and fragments that have been found derive from secondary contexts

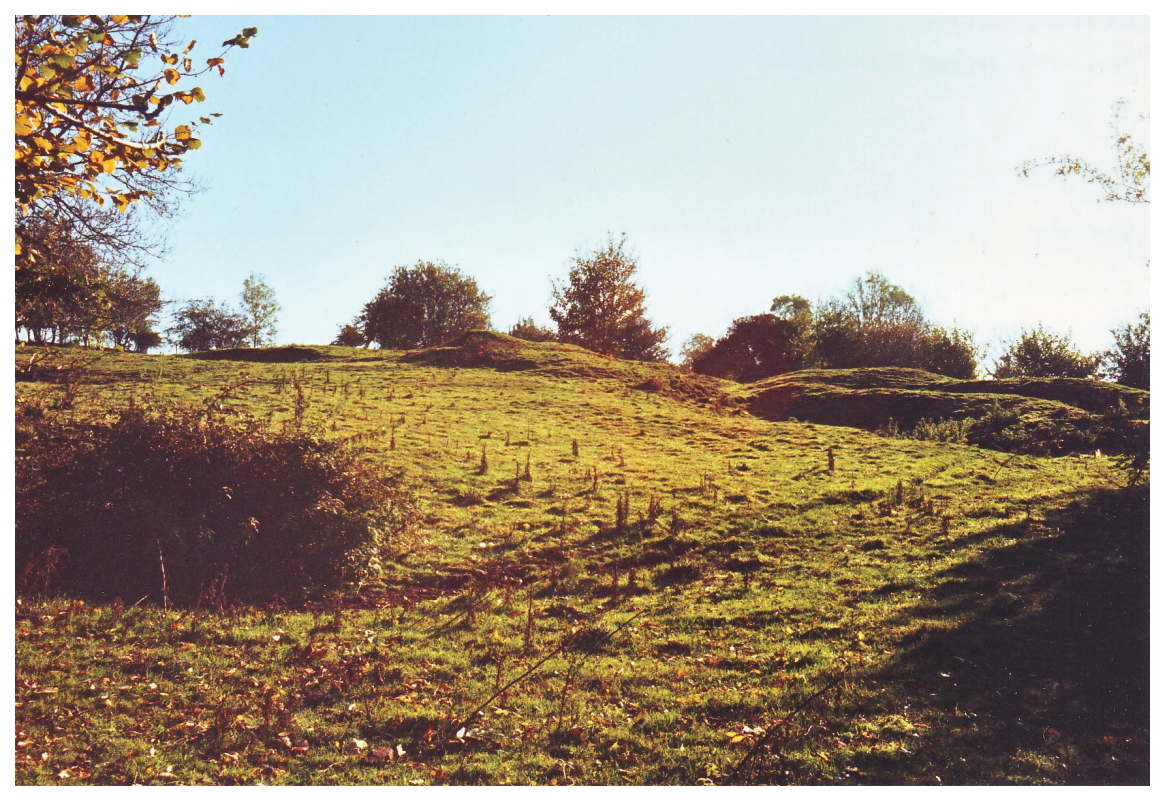

Fig. 4: The remains of Pen Pits near Penselwood, Somerset. 
and, as with rotary querns, it appears that local sources of stone were exploited.

Millstones have been recorded at several Roman sites in Somerset including Chew Park, where excavations in the 1950s recovered two upper stones of Old Red Sandstone, either from the Mendips or the Wye valley. Both stones were found re-used in late-3rd to mid4th century contexts, the more complete of the two in the floor of a corn drying or malting kiln, and so they must have been in use earlier in the site's history (Rahtz and Greenfield 1977, 56, 202, plate 25). Both stones are about $66 \mathrm{~cm}$ in diameter and it is likely, therefore, that they came from some form of geared or power-driven mill ${ }^{5}$. Another large lower stone, $71 \mathrm{~cm}$ diameter, also of Old Red Sandstone, was found re-used in the floor of a building in the Roman town of Abonae, located at Sea Mills near Bristol (Ellis 1989, 21, fig. 4, 33).

The only site in Devon to have produced millstone fragments from a Roman context is the villa site at Holcombe in the eastern part of the county close to the Dorset border (Pollard 1974). Three joining fragments from a stone originally about $74 \mathrm{~cm}$ diameter were found in late 4th century debris in a room at the northern end of the villa which had been converted to form part of a large kitchen area in the mid 4th century. The fragments were identified as being of a glauconitic sandstone, probably Upper Greensand, possibly from the nearby Blackdown Hills (Pollard 1974, 152).

About one quarter of a large, flat stone, $4.5 \mathrm{~cm}$ thick and originally about $60 \mathrm{~cm}$ diameter, which had the remains of the central eye about $10 \mathrm{~cm}$ diameter and possible evidence of a separate feed hole, was found in a 3rd to 4 th century context at Penhale Round, Fraddon, Cornwall. The fragment was initially identified as a quernstone but may in fact have derived from a millstone. It is of granite from Tregonning, about $35 \mathrm{~km}$ to the south-west of site, an area renowned for producing innovative artefacts during the Roman period (Quinnell 19989, 87, fig. 8).

\section{The Early Medieval Period, 410-1066 AD}

There is currently little evidence for querns and millstones in the south-west dating to the early medieval period, but what evidence there is indicates that, as in the Roman period, comparatively local sources of stone were utilised. At Trethurgy, for example, mentioned above, the use of rotary querns of elvan continued into the 6th century (Quinnell 2004, 151). Broken pieces of a granite rotary quern were used to line the central hearth of a building dated between the 5th and 7 th

5. The dividing line between querns and millstones is a grey area but it is considered that stones in excess of 60 $\mathrm{cm}$ diameter were too large to have been turned by hand, although conversely millstones of smaller diameter are known (Watts 2006). centuries at Gwithian, on the eastern side of St. Ives Bay, Cornwall, while further up the north Cornwall coast, at Mawgan Porth, a number of fragments from granite querns were found reused in the walls of buildings on a late Saxon settlement site, dated AD850-1050 (Nowakowski et al. 2007, 42; Taylor 1997, 129-35). Moving to Somerset, there being little of this period identified to date in Devon, a number of quern fragments were found in association with the Anglo-Saxon and medieval palace site at Cheddar. They were of a variety of materials, all identified as local, including Old Red Sandstone conglomerate, Draycott stone and also a pale andesitic lava from the Shepton Mallet area. A quarter of a fine-grained stone of Upper Greensand, possibly from Pen Pits, was also found reused in the wall of a late 10th to 12 th century structure. It was reported as a quern but its size, it was originally from a stone some $92.0 \mathrm{~cm}$ diameter, suggests that it derived from a power-driven mill. One interpretation of a circular structure, referred to as Structure $\mathrm{X}$, within the Anglo Saxon complex and dated to the 10th-11th century, is that it was an animal-driven mill (Rahtz 1979, 55, 129-32, 234, fig. 82).

\section{The Medieval Period, 1066-1540 AD}

There are similarly few surviving examples of medieval millstones, although it is possible that some fragments found in secondary contexts in later mills may be medieval in origin. Much of the evidence for medieval millstones derives, therefore, from documentary references to quarries and the purchase of millstones. These suggest that the patterns of local acquisition established in the Roman and Anglo-Saxon periods continued, with a preference for stones of Old Red Sandstone conglomerate from the Wye valley and Upper Greensand from the Pen Pits on Somerset manors, and for granite from the moors in Cornwall and Devon (Langdon $2004,164)$. In addition the importation of millstones from France is also recorded.

Although documentary evidence suggests that the Forest of Dean and the lower Wye valley were important sources of millstones for manorial mills in Somerset, production seems to have been on a small scale. Five millstone quarries within the Forest of Dean, for example, are mentioned in an account of 1435-6, but only one was actually in operation, producing just five millstones in that period (Hunt 1962, xlix; Langdon 1991, 437; Langdon 2004, 170-1). The millstones, often referred to in documentary sources as mola de Wallia (Welsh stones), were hewn to shape at the quarries and transported down the valley sides to the river Wye for shipping downstream, most probably to Chepstow (known as Striguil in the Norman period). From here they were carried down the river Severn and across the Bristol Channel to Bristol, up the river Parrett to Bridgwater in Somerset and to other ports (Thorold Rogers 1866, 511; Farmer 1992, 98-99, 110). It appears that manorial bailiffs and reeves generally purchased millstones at ports and 
other towns rather than direct from the quarries themselves (Farmer 1992). Many of the millstones bought for the mills on the Somerset estates of the Bishop of Winchester and also those of Glastonbury Abbey were Welsh stones. Documentary evidence suggests these stones were frequently distributed via Bridgwater, including a bulk purchase of twelve stones in 1453 for the Bishop of Winchester's mills in Taunton (Farmer 1992, 98, 102; Keil 1961-2, 153). Although Somerset mills may have been the main purchasers of Welsh stones in the south-west, they were also transported to mills in Devon. In 1286-7, for example, a millstone was bought for Langford Mill, Honiton in east Devon (Coxhead 1970, 175).

Another type of stone utilised for querns and millstones in Somerset during the medieval period was Upper Greensand from the Pen Pits which, as mentioned above, had been worked since the Iron Age. The Pen Pits are referred to as La Penne or Penna in medieval documents. Glastonbury Abbey is recorded as purchasing two millstones for its new windmill at Walton, Somerset in 1342; one was a Welsh stone and the other was from La Penne (Keil 1961-2, 153). Stones from Penna were also acquired by the manorial mills in Taunton (Hunt 1962, xlix; Farmer 1992, 98, 106).

There are also documentary references to the acquisition of mola francisca (French millstones) for the Bishop of Winchester's Taunton mills in the 13th and 14th centuries. Perhaps not surprisingly they were more expensive than Welsh stones or those from the Pen Pits. In the 1270s, for example, the manor of Taunton purchased a stone from Penna for 19s 1d plus $8 \mathrm{~s}^{6}$ for carriage and another, from abroad, at Wareham in Dorset for $£ 211 \mathrm{~s} 1 \mathrm{~d}$ plus 10 s for carriage. In 1301-2 a Welsh stone cost 9s, whereas two French stones cost $£ 4$ ss (Thorold Rogers 1866, 504; Hunt 1962, xlviii, xlix; Farmer 1992, 98, 103, 106; Langdon 2004, 165-6). Whether these mola francisca came from the well-known millstone production area in the Marne valley to the east of Paris or from other sources in France is not known. Quarrying of the hard siliceous stone at La Ferté-sous-Jouarre was certainly active by the mid 15 th century, with millstones being shipped via the rivers Marne and Seine (Ward 1982, 206; Belmont 2003, 282). The reason(s) why manors continued to purchase the more expensive mola francisca is unclear but Langdon $(2004,168)$ has suggested that it was probably due to a combination of factors: a consistently good quality of flour coupled perhaps with an efficient market of supply.

Further west granite continued to be used for the production of millstones which were usually

6. There were 12 pennies (d) in a shilling (s) and 20 shillings in a pound ( $($ ). Analysis by Farmer $(1992,105)$ showed that millstones broadly doubled in price between the early 13th century and the Black Death in the 1340s and had doubled again by the early 15th century. Generally speaking the purchase of millstones was the single largest expenditure for mills and in some cases could exceed their annual income (Langdon 2004, 162). made from surface boulders, known as clitter or moorstones. In some respects it is surprising that granite millstones were so popular for although the stone is durable, it takes a good polish and requires frequent dressing to keep the milling surfaces textured. But it was an easily and locally available material and indeed stones of Dartmoor granite appear to have been sought after and widely distributed throughout Devon.

In the 15th century, for example, millstones from Dartmoor were obtained by manorial officials of the Earl of Devon and the Dean and Chapter of Exeter for mills in Tiverton in mid Devon and Sidbury in south-east Devon respectively (Fox 1991, 153). It appears that, like the quarries in the Forest of Dean, granite millstone making enterprises during the medieval period were small scale. On Dartmoor the millstone makers appear to have been either tenant farmers or their landless sons who probably practised their craft on a seasonal basis (Fox 1994, 154-5). It was not uncommon for the lords of the manor to take a toll for each millstone made.

In the 1330s-1340s millstone makers on the Priory of Plympton's manor of Shaugh, on the southern side of Dartmoor, were charged $5 \mathrm{~d}$ or $6 \mathrm{~d}$ per stone. Such operations were not always above board, however. A 16th century survey of the manor of South Brent, also on the southern side of Dartmoor, records that there were:

... many great Rockes of stone of which the masons of the countrey thereabouts have used heretofore often tymes to make myll stones and so carryed awaie and solde the same without any knowledge or recompence given the lorde (Robinson 1981, 334; Fox 1994).

Millstone production seems to have been on a similar small scale in Cornwall. Two quarries documented at Stoke Climsland and Rillaton on the edge of Bodmin Moor produced only seven millstones between them in 1338-9. The Climsland quarry was a short-lived site, ceasing production in the 14th century but Rillaton continued to produce millstones sporadically into the 16 th century (Langdon 2004, 170).

Although Dartmoor granite was the principal source for millstones in Devon in the medieval period, other sources are also recorded. A millstone quarry at Kenn, on the west side of Exe estuary near Exeter, is recorded in 1422, the stone presumably being the local New Red Sandstone. Stones from Kenn were sent to mills in Topsham, Bradninch near Tiverton and Sidbury, some $9.5 \mathrm{~km}, 32 \mathrm{~km}$ and $16 \mathrm{~km}$ from Kenn respectively (Fox 1994, 156 n5).

Another source of New Red Sandstone was once to be found at Corbyn's Head in Torbay, where a millstone quarry is documented in 1196. Traces of extraction pits were recorded in the 1930s but subsequent erosion of the cliffs has removed all vestiges of the quarry (English Heritage Pastscape Monument No. 1466179).

As mentioned above, there are few identifiable surviving examples of medieval millstones. Two granite millstones found during the excavation of a late 12 th - early 13 th century manor house at Penhallam in north Cornwall, had been reused as 


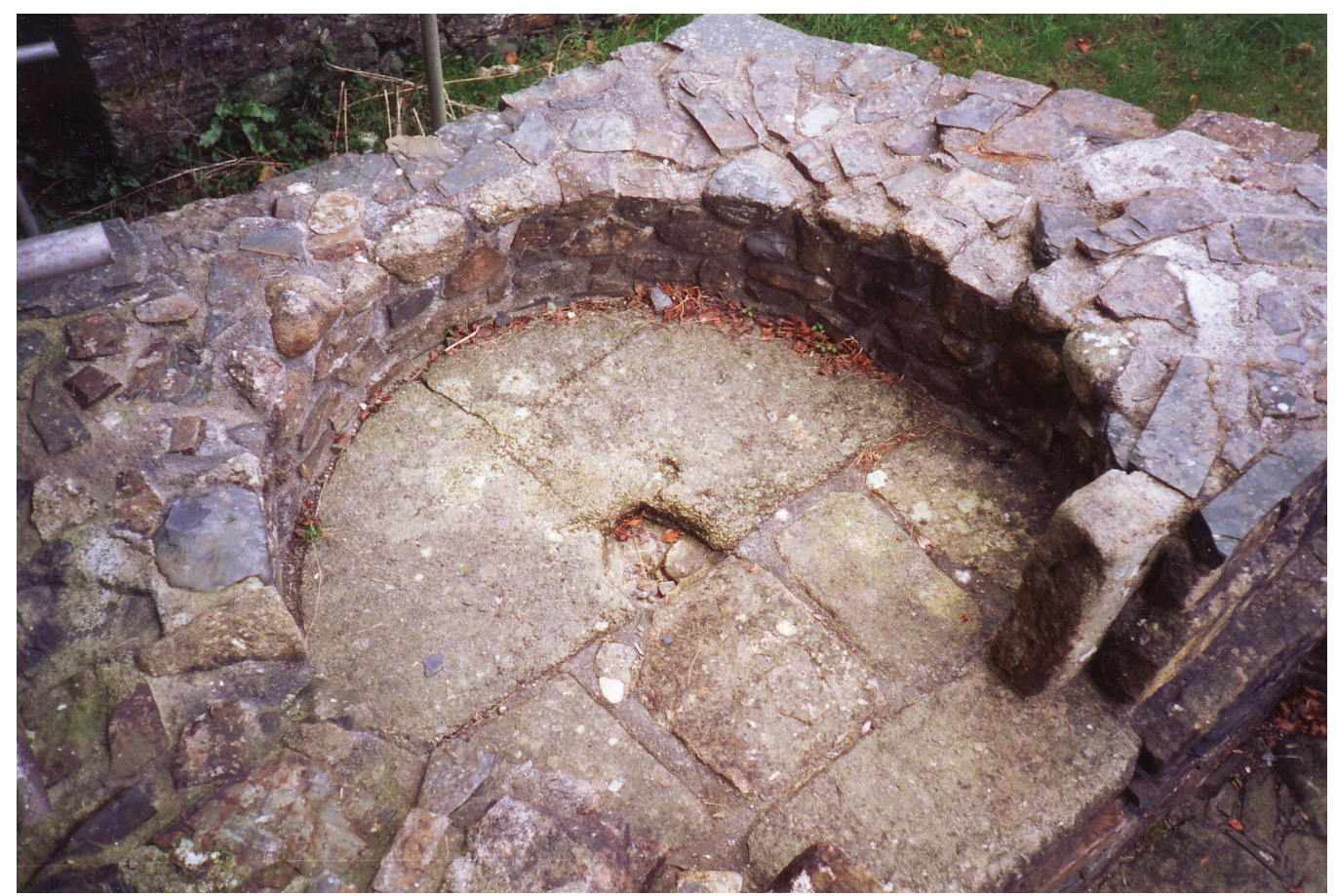

Fig. 5: Granite millstone reused as an oven base at Okehampton Castle, Devon.

hearths in the hall and kitchen (Beresford 1974, 108, 111-2, fig. 27). It was considered that these stones, both $1.2 \mathrm{~m}$ in diameter, had come from a local mill and they are likely, therefore, to be amongst the earliest identified granite millstones in the region. The granite millstone built into an oven base at Okehampton Castle in Devon in the 17th century is possibly of medieval origin (Fig. 5) (Higham 1991, 14, 24).

It is often presumed that in the medieval period manorial tenants were compelled to have their grain ground at the lord's mill and that the use of querns was prohibited. For many, but not all, this was the case. In Barnstaple in north Devon, for example, when the Priory of St. Mary Magdalene was endowed with the town mill in 1107, the townspeople were bound to grind their corn there, a dictat that remained in force until 1328 (Devon Historic Environment Record No. MDV882). As late as 1690 , one W. Higgins was charged with not having his corn ground at the customary mill, in this case Manor Mill, Salcombe Regis, Devon (Wilson 1978, 36). However, freemen were allowed to use querns and many monasteries and manor houses, including Penhallam in Cornwall, mentioned above, had querns for grinding malted grain for brewing, and for mustard and other spices. Most of the medieval querns in the south-west known to the authors are from sites in Cornwall and Devon and, as might be expected, the stones tend to be of granite or elvan.

But there are, of course, exceptions. Three of the four fragments of pot quern found in the bakehouse at Penhallam manor were of Pennant Sandstone; the fourth fragment was thought to be of Sutton Stone $^{7}$ from the Bridgend area in South Wales (Smith 1974, 143-145). As at Trethurgy, mentioned above, the presence of such querns must point to particular relationships or trading contacts.

Although there is evidence for a revival of the trade in lava querns from the Eifel district in Germany elsewhere in England from at least the 7th century, very few examples have been found in the south-west. The fragments found in medieval contexts at Calstock, Cornwall are considered to be residual from the military occupation of the site in the Roman period. There is, however, an unverified report of a lava pot quern base found at Totnes in south Devon and the upper stone of a pot quern was apparently found when a wall at Catcott in Somerset was demolished prior to 1954 (Somerset Historic Environment Record No. 10328).

\section{The Post-Medieval period, 1540-1750}

References to mustard mills and malt mills in household inventories from the 16th and 17th centuries indicate that querns were still in common use in the earlier post-medieval period for grinding small amounts of grain and spices for home consumption (see for example Cash 1966). A number of the pot quernstones found at farms and former manor houses, such as Cotehele on the west bank of the Tamar in Cornwall, were probably in use in

7. Sutton Stone is a Jurassic conglomerate that outcrops in South Wales (Johnson and McKerrow). 

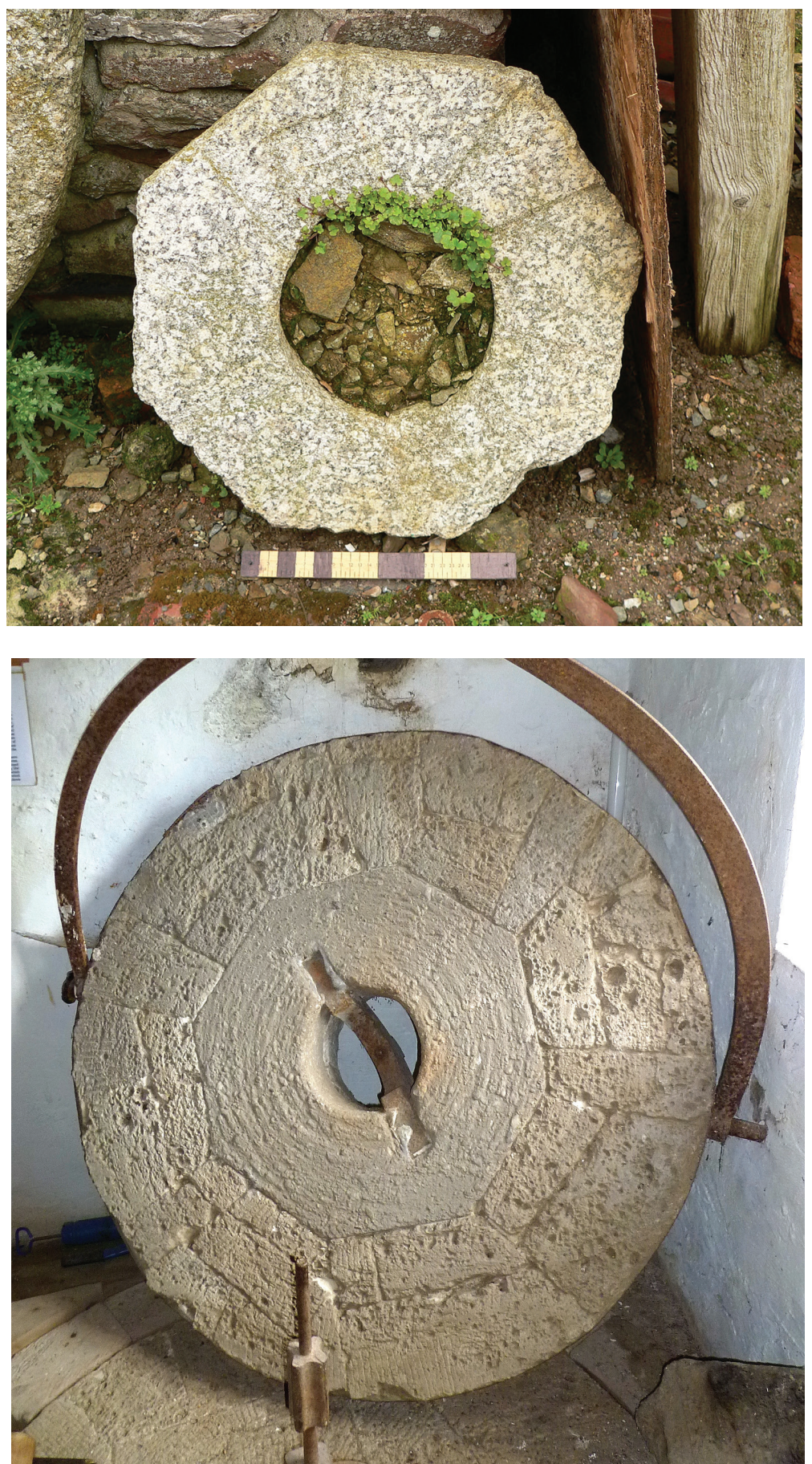

Fig. 6: Granite millstone centre at Insworke Mill, Cornwall (left) and French burr stone with a conglomerate centre at Hele Mill, Ilfracombe, Devon (right).

the late medieval - early post-medieval period, but by the end of the post-medieval period querns were going out of use across the region. The exception was on the Isles of Scilly where they remained in use until at least the mid 18th century, there being only one corn mill, the windmill at Peninnis, St. Mary's, at that time. Today many rotary querns can still be seen leaning up against house walls on the islands; all are of granite (Borlase 1756, 28: Ratcliffe 1991, 67).

Although a number of surviving mill buildings in the south-west retain fabric dating from the early post-medieval period, such as Bidlake Mill in Bridestowe, Devon and Piles Mill at Allerford, Somerset, their extant millstones, where they survive in their working positions, are later in date. However, it is likely that many of the millstones reused in the floors and walls of mills that were rebuilt in the late 18th and 19th centuries derive from the post medieval - early modern periods. A rapid survey of millstones found in secondary contexts in mills visited by the authors shows granite to be the most frequently re-used stone in Cornwall, although there are also some examples of Old Red 


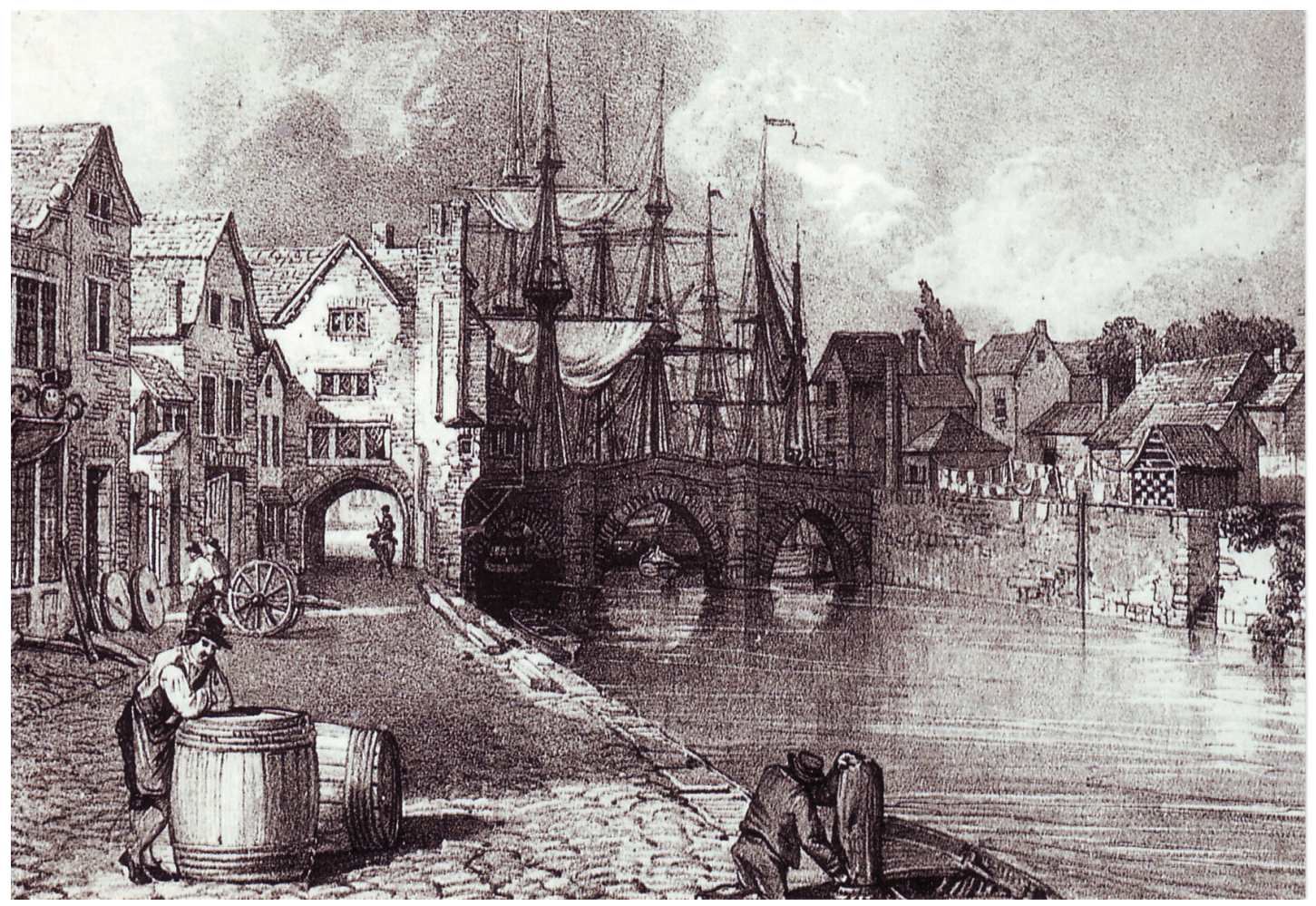

Fig. 7: Millstones on the quay at Bridgwater, Somerset, probably 1790s (engraving after John Chubb, courtesy of the Blake Museum, Bridgwater).

Sandstone conglomerate (Welsh stones), particularly in the east of the county. In Devon residual stones tend to be Welsh, French or granite with some stones of Millstone Grit (commonly known as Peak stones after the high moorland area in Derbyshire where the majority of such stones were sourced $^{8}$ ) and the occasional stone of local Permian breccia. In Somerset there is evidence for re-used Welsh stones with some French and Peak stones. While is not possible to date these stones with any certainty, the implication is that by the end of the postmedieval period, if not earlier, Welsh stones were being imported into Cornwall and that the main types of stone used in the south-west were granite, Welsh and French, with some evidence also for the use of Permian breccia and for the importation of Peak stones (but see below).

As mentioned above, the quarries at La Fertésous-Jouarre were in production by the mid 15 th century and by the end of the 16 th century burrs the individual blocks which were shaped, cemented together, backed with plaster of Paris and banded

8 Millstone Grit is a particularly hard coarse-grained sandstone with robust quartz grains. Its name comes from its long and widespread use for milling stones. It is part of the Carboniferous formation of the Pennines in northern England which runs from Northumberland southwards though the Yorkshire dales to the Derbyshire Peak District. It can be confused with Old Red Sandstone but the grains are much coarser and it is not usually pebbly (Stanier 2000, 47; Shaffrey 2006, 8). with iron hoops to form millstones - were being imported into England (Ward 1993, 8, 29-30). Twenty five burrs and two burrs 'most of them used', together with pieces of plaster of Paris, are recorded in an inventory dated 1615 for Morden Mill, located close to the river Tamar near Cotehele in east Cornwall (Cornwall Record Office ME 1959). The implication is that these pieces were from a broken stone or stones and the early 17 th century date is significant, therefore, as one of the earliest references to such stones being used in England. Interestingly, two early advertisements for French millstones in the London Gazette dated 1689/90 and 1708 are for ship loads of burrs at Dartmouth and Plymouth respectively, both ports in Devon (Ward 1993, 29).

An interesting feature of millstone making found in Devon and Cornwall is the use of a local stone centre, usually granite, around which the rest of the millstone was built up of blocks of French burr (Fig. 6). Chudleigh Bridge Mills in Devon, for example, is recorded as having three pairs of stones, one of which was a French stone with a 'moor', that is a granite, 'eye' (Western Times, 9 September, 1848). This was a practical economy as the central part of the millstone, where the grain is drawn in and preliminary breaking occurs, does not need to be of such good quality stone as the skirt or grinding zone where the finer reduction is done. It is possible that the use of granite centres dates back to the medieval period (Tangye 1992) but most extant centres are probably post-medieval or early modern in date. 
Welsh stones of Old Red Sandstone conglomerate continued to be imported from the Forest of Dean and the Wye Valley; there are documentary references to 'millstone hewers' in the Forest of Dean in the 17th and 18th centuries (Smyth 1608; Tucker 1973, 11). Chepstow remained the main entrepôt for millstones brought down the Wye, with Bridgwater continuing to be an important market centre (Tucker 1971, 236; Hussey 2000, 5). Indeed, in the 1560s and 70s Bridgwater Corporation had a monopoly on the purchase and resale of millstones from the Forest of Dean. In 1572 a variety of stones, including millstones, grindstones and mustard mill stones are recorded as being were stacked on the quay and as many as 76 stones were sold there in 1590-1 (Fig. 7) (Dunning 1992, 36). In 1696-7, a new millstone, presumably Old Red Sandstone, was bought for the Town Mill in Lyme Regis on the Dorset coast, close to the Devon border, from Edmund Petit of Bridgwater (Graham et al. 2005, 66). Millstones were also shipped down the north Devon coast to Barnstaple, not just from Chepstow but also from Bristol and Gloucester (Tucker 1971, 236; Thorpe 1989, 24).

\section{The Modern Period, 1750-present day}

The trade in Welsh stones continued into the modern period. In 1802, for example, they were being imported into south Devon via Dartmouth and Exeter by Samuel Flood, a miller and baker of Broadclyst near Exeter (Sherborne Mercury 12 April, 1802). Indeed, as late as the 1870s the Gloucester millstone maker William Gardner was still advertising Welsh millstones direct from the quarries and 'Noah Hudson, millstone maker, Penallt' is recorded

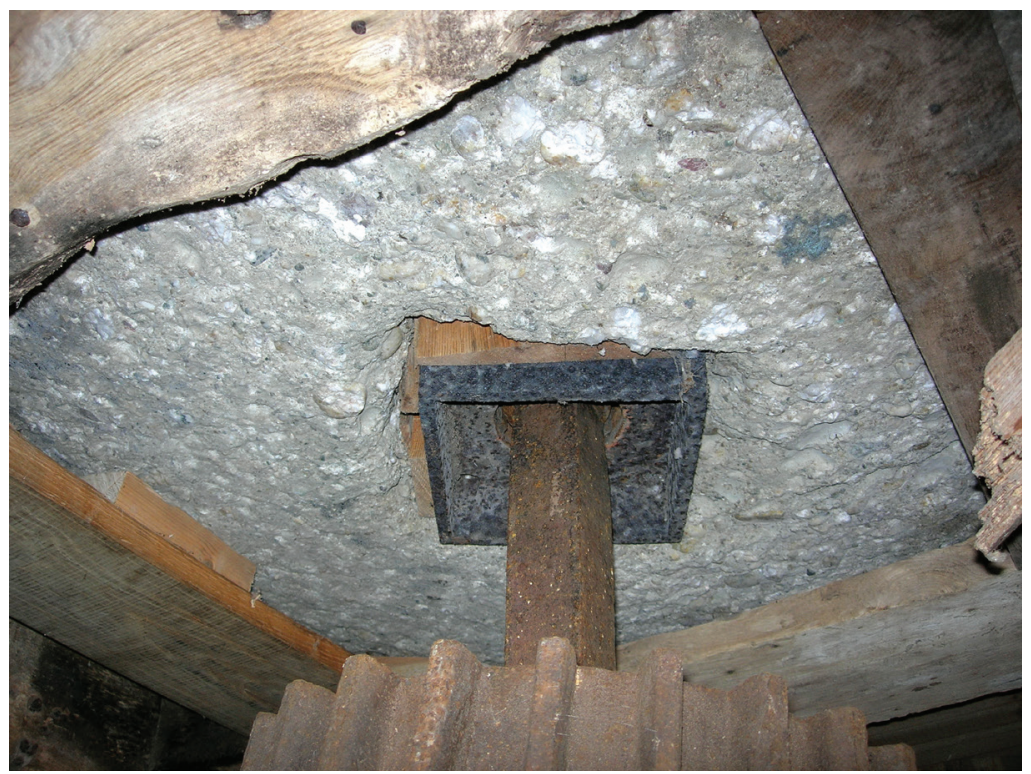

Fig. 8: Welsh conglomerate bedstone at Dowrich Mill, Sandford, mid Devon.

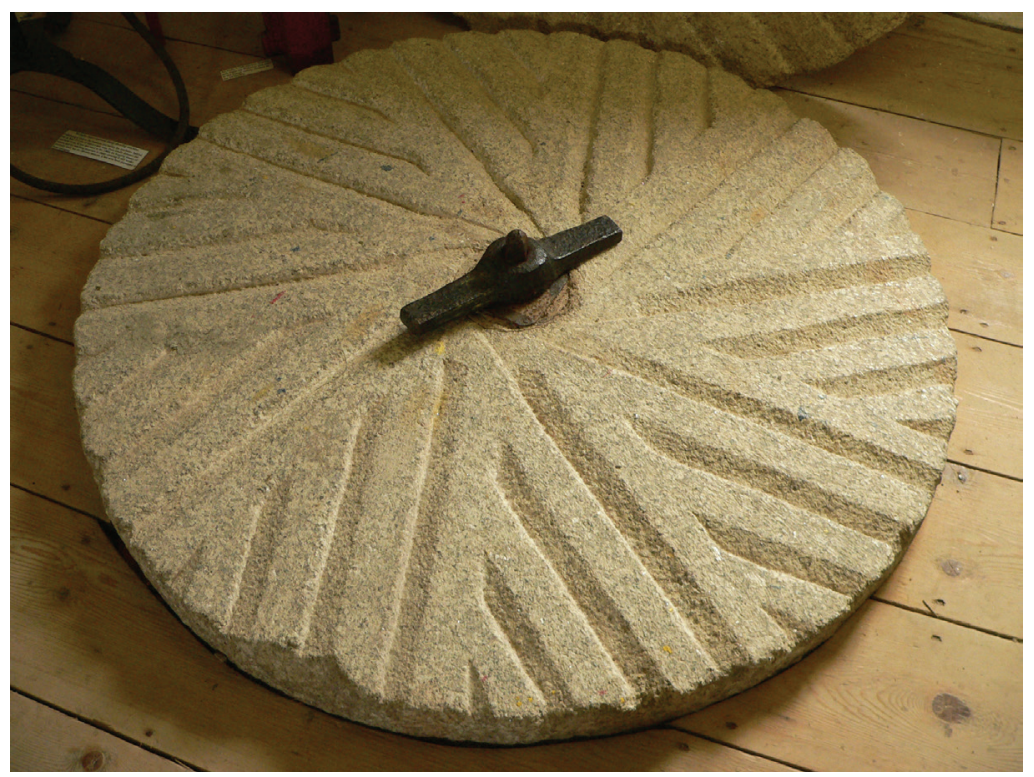

Fig. 9: Granite millstone at Trewey Mill, Zennor, west Cornwall. 


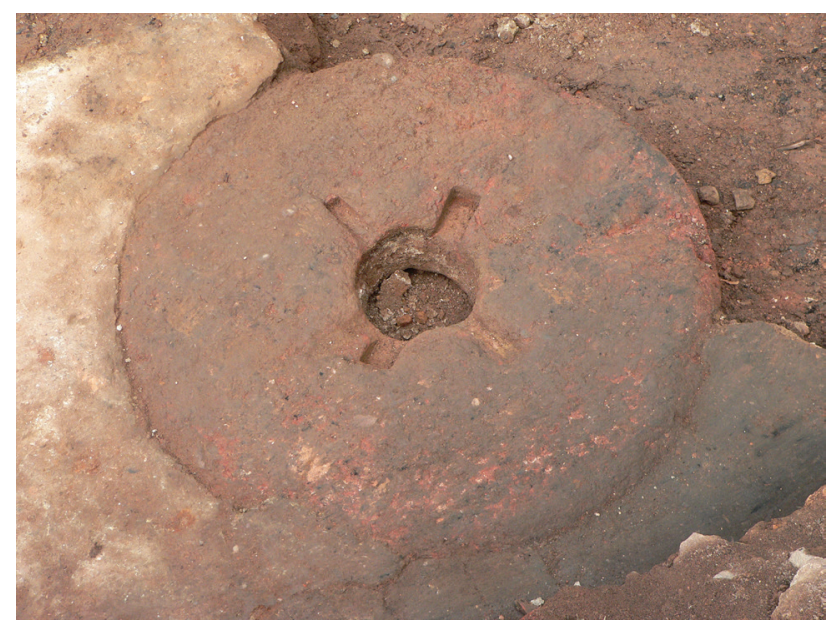

Fig. 10 : Breccia millstone reused in the floor of Dotton Mill, east Devon.

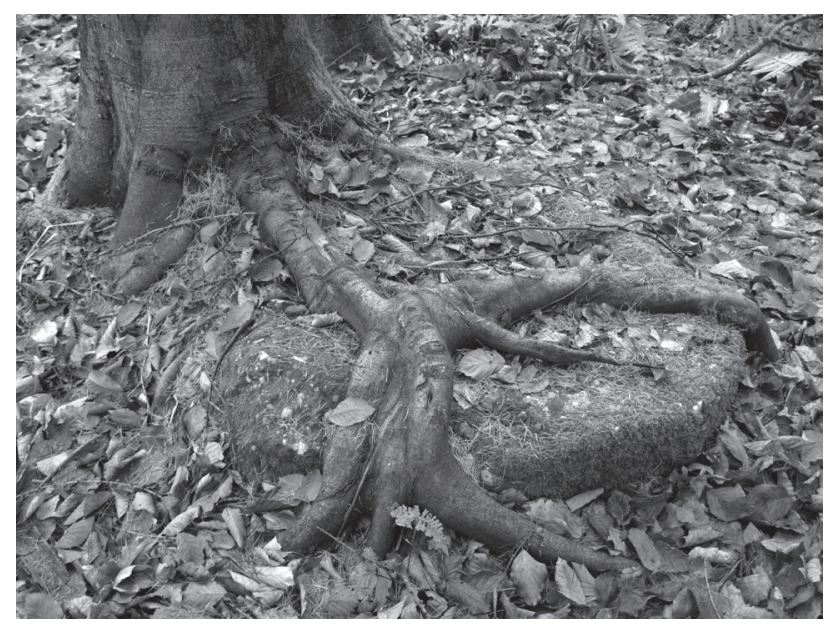

Fig. 11. Abandoned Old Red Sandstone conglomerate millstone, Mill Wood, St Briavels, Gloucestershire (Courtesy of Alan Stoyel).

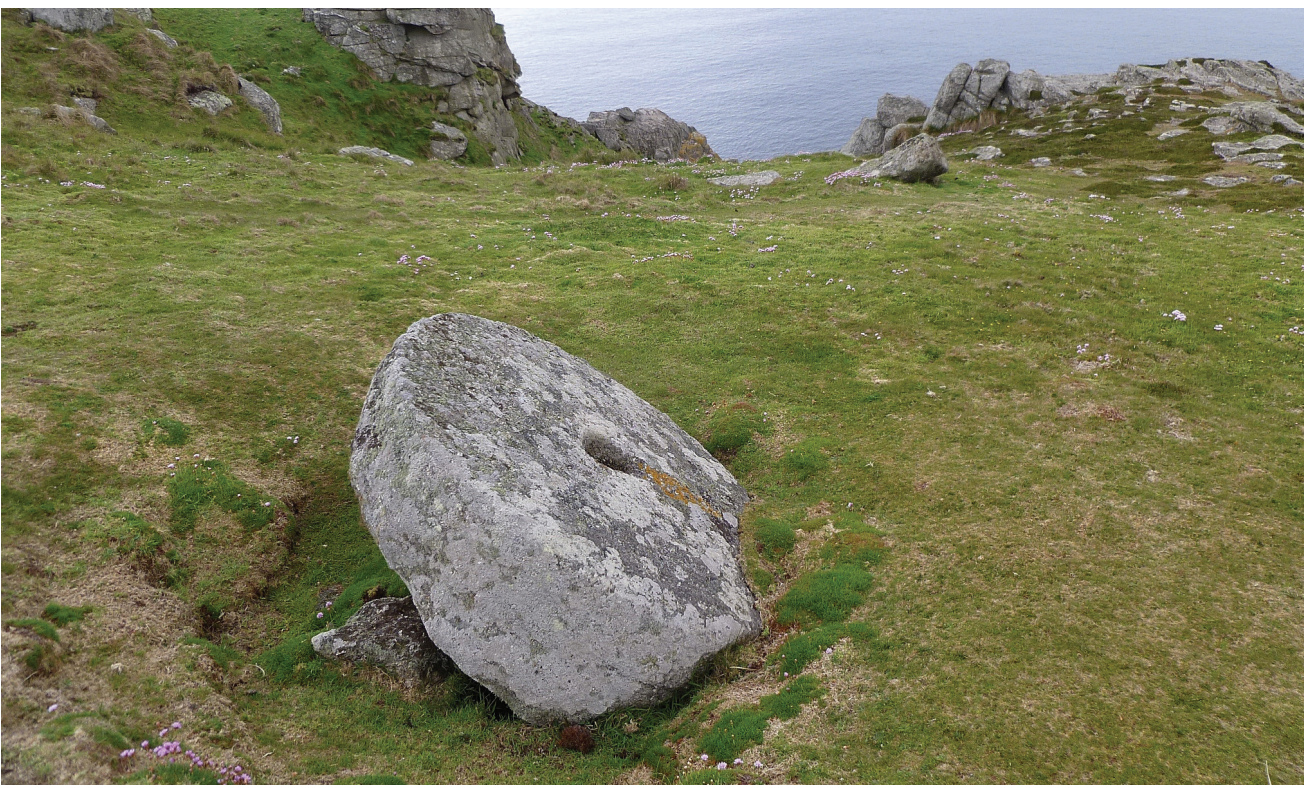

Fig. 12: Unfinished granite millstone on Lundy.

in Kelly's Directory for 1884 . Some late-18th and early-19th century adverts for the sale of mills in local papers identify the types of millstone as well as stating the number of pairs in a particular mill. These are too few in number to determine any patterns of distribution but, as indicated above, they confirm that by the early modern period the trade in Welsh stones had spread across Devon into Cornwall. Pencare Mill, Landrake in east Cornwall, for example, is described as 'newly erected' in 1808 with three pairs of stones, Welsh, French and granite (Sherborne Mercury, 5 December, 1808). Welsh stones can still be found in their working positions in a number of mills in the south-west, including Manor Mill, Roadwater, Somerset, Dowrich Mill, Sandford, Devon and Trelaske Mill, Lewannick and Ridgegrove Mill, Launceston in Cornwall (Fig. 8).

As Pencare Mill illustrates, the use of granite millstones also continued. William Crossing, writing in 1912, commented that he had "known those who remember when it was customary to go to [Dart] moor to cut stones for the corn mills' (Messurier 1981, 386). However, it is noticeable that very few advertisements specifically mention granite millstones, that for Pencare Mill being unusual in this respect. It is also of note that although they can be found at many mill sites in Devon and Cornwall, granite millstones are now rarely found in their working positions. Exceptions have been noted at Trewey Mill, Zennor in west Cornwall, Melinsey Mill, Veryan also in Cornwall and Bidlake Mill, Bridestowe, on the north side of Dartmoor (Fig. 9).

A small number of mills in Devon also used stones made from Permian breccia, a material first exploited for querns in the Iron Age and Roman periods. Known as 'grout stones', these were coarse millstones used for de-husking wheat and also shelling clover (Vancouver 1808, 72, 124). None has been found in situ but breccia millstones have been identified, re-used as flooring material, at Dotton 
Mill in east Devon and in New Mill, North Bovey on Dartmoor (Fig. 10).

By the end of the 19th century the local millstone industry had faded. This demise can be ascribed firstly to the dominance of Peak stones of Millstone Grit and, more particularly, French millstones (see below) and, secondly, to the introduction of iron rolls in roller flour mills (Tucker 1971, 238; Tucker 1973, 8, 11-12; Mullin 1988, 53). Unfinished stones and broken blanks, mute evidence of the former industry, can still be found abandoned in the Wye Valley and Forest of Dean (Fig. 11) and also on Dartmoor and on Lundy, an island off the north coast of Devon (Fig. 12). The date of their extraction is unknown but they are likely to belong to the final period of millstone making in these areas.

Peak stones had become much more widespread in England in the post-medieval period. In 1692 it was noted that Derbyshire had 'rich Quarries of Mill-stones and they serve most part of the Kingdom' (Hey 1980, 140-1). However, these stones were not common in the south-west until the 19th century when improved transport facilities and marketing by millstone dealers and mill furnishers made them a more attractive and perhaps more economic proposition. In 1915 the London-based millstone manufacturers William Garner and Sons quoted for the supply of a pair of best quality Peak stones to a customer in Stogumber, in west Somerset, to be delivered to Honiton station (Garner 1915). But although found in mills in Somerset and Devon, it is noticeable that Peak stones are not common in Cornish mills, two exceptions being Ridgegrove Mill, Launceston and Trouts Mill, Menheniot, both in east Cornwall. Here, as indeed in Devon and Somerset, it was the French burr stones that were to prevail.

French burr stones were generally considered to be far superior to native stones for producing fine white flour'. It is noticeable that many more 19th century advertisements refer to mills as having French stones than Welsh or granite stones and none of those seen specifically mention Peak stones. Batheaston and Twerton Mills, near Bath, for example, were described in 1744 and 1797 respectively as newly built, both with two pairs of French stones and Portishead Mill near Bristol was advertised in 1771 as 'new-built' with 'three Pair of Stones, two French, the other Welch' (Bath Journal 24 December, 1744; Bristol Gazette, 2 March, 1797; 12 September, 1771). Tawton Mills, Bishops Tawton, north Devon was advertised in 1796 as having six pairs of stones, two of them French and quite new. Similarly, Clapworthy Mill, Chittlehampton, also in north Devon, was advertised in 1861 as recently erected and containing three pairs of stones, two pairs of them French. The material of the other pairs

9. French burr stones produce a meal with larger pieces of bran compared to indigenous stones such as Millstone Grit which can be more easily sifted out to produce a fine, white flour. The porous texture of the stone also meant that millstones kept their grinding edges without the need for dressing although the latter, given the hardness of the stone, was long-lasting (Ward 1982, 205). of stones is not mentioned (Sherborne Mercury, 15 February, 1796; Exeter Flying Post, 17 July, 1861). Chudleigh Bridge Mills had, as mentioned above, three pairs of stones, one French, one Welsh and the third, French with a granite centre (Western Times, 9 September, 1848). In Cornwall, Merther Uny Mill, Gweek had one pair of Caen (French) stones and one pair of Moor (granite) stones in 1779, and in 1832 Heskyn Mill, St. Germans was described as having four pairs of stones of which three pairs were French (Sherborne Mercury, 5 January, 1779; 27 August, 1832). There is also some evidence for the replacement of native stones with French stones. Dunster watermill in west Somerset was advertised in 1783 as having two pairs of French stones and two pairs of Welsh stones (Bristol Gazette, 20 February, 1783). Today it has three pairs of French stones (the fourth pair was removed some time ago). Tipton Mills, Ottery St. Mary, in east Devon had three pairs of French stones and one pair of Welsh in 1797 but by 1803 it had four pairs of French stones (Sherborne Mercury, 9 January, 1797; 9 May, 1803).

As in earlier times, French stones were always the most costly type of stone. In an account of repairs carried out between 1779 and 1781 at Dunster Mill, mentioned above, the most expensive single item was the purchase and installation of a pair of French millstones which were brought from Bristol and cost a total of $£ 4717 \mathrm{~s} 8 \mathrm{~d}$ (Somerset Record Office DD/L1.33.51). Most French stones appear to have been built by specialist millstone makers at ports and distribution centres such as Exeter, Bristol and Gloucester and a single stone could comprise upwards of 20 burrs, usually with four blocks neatly formed around the eye and the remainder cut to wedge shapes and set radially to form the skirt (Fig. 13). It was not uncommon, however, for a French burr stone to be paired with a native stone. Town Mills, Cannington, Somerset was advertised for sale in 1789 with three pairs of stones, one pair French, one pair Welsh and the third pair French and Welsh (Sherborne Mercury, 27 April, 1816). Pairings of French and Welsh stones can still be seen at Stembridge windmill, High Ham and Hinton Mill, Mudford, in Somerset and Thuborough Mill, Sutcombe in Devon. Such pairings may well have been made for economic reasons although Ward $(1993,17)$ cites a French text of 1847 which commented that 'experience commends the use of a bedstone softer than the runner'10. And, as mentioned above, it was also not uncommon for French burrs to be built up around a granite or Welsh stone centre.

10. Stembridge windmill and Thuborough Mill have French runners with Welsh and granite bedstones respectively, as recommended. Hinton Mill, however, has a French bedstone with a Welsh runner. There are also examples of different native stones being paired together such as the Welsh and Peak stones at Pen Mill, Yeovil recorded in an advert of 1756 (the mill also had a pair of French stones) (Sherborne Mercury 24 March 1756). 


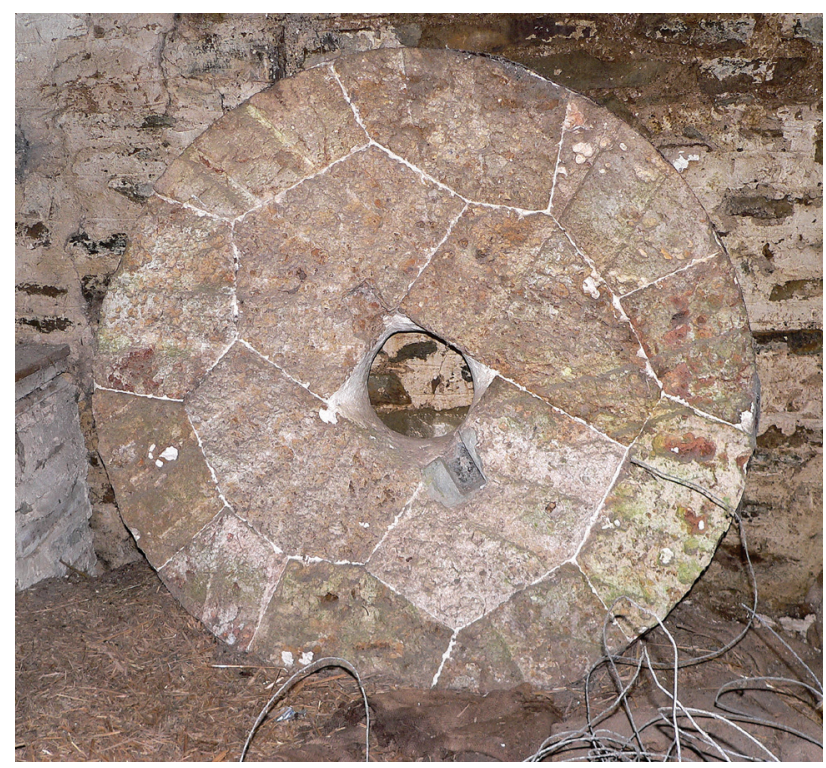

Fig. 13: French stone at Cawsey Meethe Mill, north Devon, made up from 14 individual blocks or burrs.

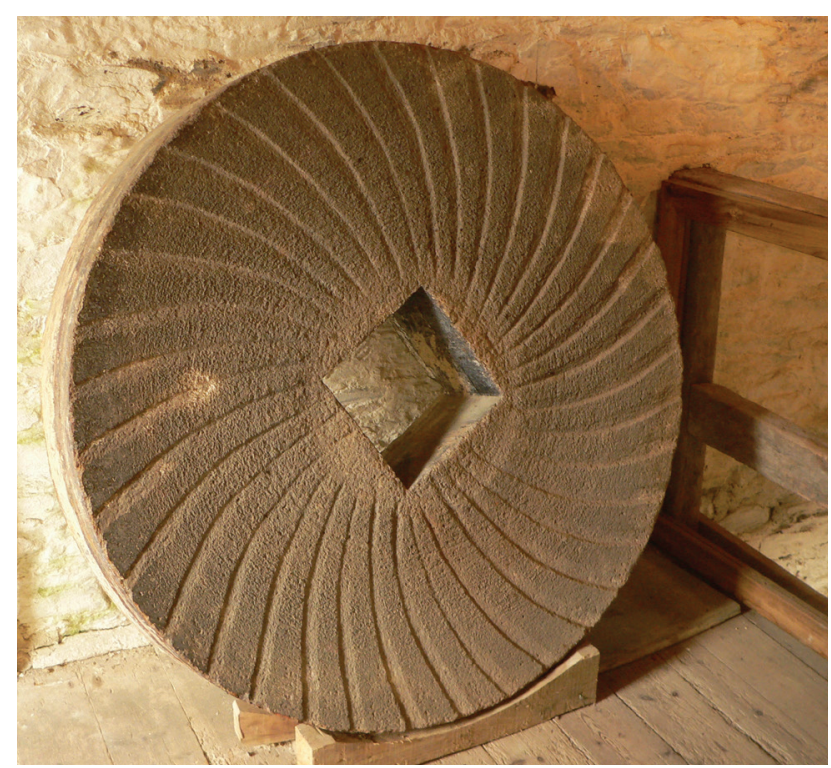

Fig. 14: Composition millstone with typical curved furrow dressing at Cotehele Mill, east Cornwall.
Finally, artificial composition millstones were introduced in the late 19th century, having been developed for general purpose milling (Fig. 14). From the early 20th century until 1969 they were manufactured in Gloucester by Barron \& Son Limited who, according to an early catalogue, produced about 1000 pairs of millstones a year (Barron nd, 12; Mills 2007). The millstones comprised a mixture of cement with a grinding medium such as French burr chips (white/yellow in colour), granulated rock emery (brown) or basic slag (black) which were bonded together with a mix of calcined magnesite cement and diluted magnesium chloride to form the milling face (Scrivens 1976). The stones were cast in moulds with tangential (straight) or curved furrows and banded with iron or steel hoops. The French burr type was used for milling grain for human consumption and the emery and slag types for animal feed (Barron nd, 12). Composition stones survive at a number of mills including Ashton Windmill and Burcott Mill in Somerset, Town Mills, Chudleigh, Otterton Mill and Cricklepit Mill, Exeter in Devon and Cotehele Mill, Cornwall.

\section{Discussion and conclusion}

In looking at the sources and distribution of querns and millstones used in a specific region of England over a period of more than two millennia, an immediate problem is the inconsistency of information available. It is interesting to note, for example, that it is far easier to identify and ascribe dating parameters to Roman querns and millstones than it is for the following millennium. While there is substantial documentation for the medieval period, particularly with regard to manorial records which have been skilfully quarried by historians such as David Farmer and John Langdon, cited above, there is a lack of physical data because of the paucity of datable finds. Where have all the millstones gone? There is also much valuable documentation, both technical and economic, as well as many survivals of millstones from the 19th and early 20th centuries, at the end of the tradition of milling with stones. It is, however, difficult to date millstones re-used as building material except to say that they belong to an earlier mill building, or to an earlier configuration of machinery. Similarly, it is almost impossible to date the unfinished and broken stones lying abandoned in former quarry workings with any great accuracy, although it seems most likely that many belong to the final phases of production.

This overview is but the result of preliminary research into the types of stone used for the manufacture of rotary querns and millstones in the south-west of England and future work, both documentary and in the field, will undoubtedly refine the current data and the results concluded from it. Nevertheless, despite the inconsistencies in information and the inherent difficulties of dating stones, current evidence indicates several patterns of supply and distribution. Firstly, a greater variety of stone types was used for quernstones than for millstones. Indeed, as Peacock $(1980,43)$ commented, it seems 'almost any suitable outcrop' was quarried. Consequently, although there are exceptions which can be attributed to particular trading or social relationships, there is a gradual shift in stone type from granite, elvan and greisen in the west of the region through Permian volcanic stones and sandstones in the Exeter area and Hangman and Foreland gritstone on Exmoor, to Upper Greensand and Old Red Sandstone in the east. The exception was the use of imported lava querns from the Eifel region of Germany during the Roman period, which seems to have been the province of the military in 
the region at that time. However, stones of German lava are notable by their almost complete absence in later periods.

Millstones also originally tended to be fairly locally sourced. A particularly important source of millstones for Somerset was the Old Red Sandstone conglomerate (Welsh stones) from the Wye Valley and the Forest of Dean. Further west, in Devon and Cornwall, granite was utilised but a gradual increase in the use of Welsh stones is also evident in these areas from the post-medieval and early modern periods onwards, if not before. However, it was not until the 19th century that stones of Millstone Grit from the Peak District of Derbyshire began to be imported into the region in any quantity. Of far more import were French burr stones which, despite their higher cost, were considered to be superior for the production of white flour. Documentary evidence for the importation of mola francisca dates back to the medieval period and by the end of the 19th century their use had superseded that of native millstones. This, together with the introduction of iron rollers in the large, steam-driven mills, spelt the beginning of the end for the local millstone quarries. Thus from the plethora of different stone types evidenced for the manufacture of querns in the Iron Age and Roman periods, the number used for millstones at the end of era of traditional corn milling had dropped to a mere handful, namely granite, Old Red Sandstone conglomerate, Millstone Grit, French burr and artificial composition stones.

\section{Acknowledgements}

The authors would like to take this opportunity to acknowledge Martin Bodman's work in transcribing numerous advertisements for water and wind mills from the Sherborne Mercury, Exeter Flying Post and other 18th and 19th century south-western newspapers. We are also grateful to Alan Stoyel for the Barron catalogue and the permission to reproduce Figure 5, and Chris Webster and the Blake Museum, Bridgwater for permission to reproduce Figures 1 and 7 respectively. All other photographs and illustrations are by the authors.

\section{Bibliography}

BARFORD, P.M. (1984). Some Possible Quern Quarries in the Bristol Area: A Preliminary Survey. Bristol and Avon Archaeology, 3: 13-17.

BARRon, nd. Undated early-twentieth century trade catalogue in the collection of A. Stoyel.

Bell, M. AND Bradshaw, R. (1983). Roman Lava Querns from Exeter. Proceedings of the Devon Archaeological Society, 41: 128-30.

Belmont, A. (2003). Commerce et Diffusion des Meules de La Ferté-sous-Jouarre aux XVe et XVIeS. In: M. Barboff, F. Sigaut, C. Griffin-Kremer and R. Kremer, R. (eds). Meules à Grains. Paris: 282-8.

Beresford, G. (1974). The Medieval Manor of Penhallam, Jacobstow, Cornwall. Medieval Archaeology, 18: 90-145.

Borlase, W. (1756) (reprinted 1966). Observations on the Ancient and Present State of the Islands of Scilly. Newcastle.

Buckman, J. (1866). On the Materials of Roman Querns. Wiltshire Archaeological Magazine, 9: 291-4.

CASH, M. (ed.) (1966). Devon Inventories of the 16th and 17th Centuries. Devon and Cornwall Record Society, N.S. 2.

Coxhead, J. R. W. (1970). Accounts of the Manor of Honiton, 1286-7. Devon and Cornwall Notes and Queries, 31: 173-80.

Crawford, O.G.S. (1953). Archaeology in the Field. London.

Dunning, R.W. (1992). Bridgwater, History and Guide. Stroud.

Ellis, P. (1989). Sea Mills, Bristol: The 19651968 Excavations in the Roman Town of Abonae. Transactions of the Bristol and Gloucester Archaeological Society, 105: 15-108.

FARMer, D. L. (1992). Millstones for Medieval Manors. Agricultural History Review, 40.2: 97-111.

Fox, H.S.A. (1991). Devon and Cornwall. In: E. Miller (ed.). The Agricultural History of England and Wales 1348-1500, 3. Cambridge.

Fox, H.S.A. (1994). The Millstone Makers of Medieval Dartmoor. Devon and Cornwall Notes and Queries, 37.5: $153-57$.

GARNER, W. (1915). Quotation letter in the collection of M. Watts.

Graham, A., Draper, J. and Watts, M. (2005). The Town Mill, Lyme Regis: Archaeology and History AD 1340-2000. Lyme Regis. 
Hesketh, R. (2008). Devon's Geology. Launceston.

Hey, D. (1980). Packmen, Carriers and Packhorse Roads: Trade and Communications in North Derbyshire and South Yorkshire. Leicester.

Higham, R.A. (1991). Okehampton Castle, Devon. London.

Hunt, T.J. (ed.) (1962). The Medieval Customs of the Manors of Taunton and Bradford on Tone. Frome.

Hussey, D. (2000). Coastal and River Trade in Pre-Industrial England. Bristol and its Region 1680-1730. Exeter.

Ingle, C. (1984). A Petrological Study of some Quernstones from the Bristol Region. Bristol and Avon Archaeology, 3: 8-12.

Johnson, M.E. And McKerrow, W.S. The Sutton Stone: An Early Jurassic Rocky Shore. Deposit in South Wales. http://www.pass-pubs.org/palaeontology/pdf/ Vol38/Pages\%20529-541.pdf, accessed 21 August 2014.

KeIL, I. (1961-2). Building a Post Windmill in 1342. Transactions of the Newcomen Society, 34: 151-4.

Kempe, D.R.C. and Harvey, A.P. (eds) (1983). The Petrology of Archaeological Artefacts. Oxford.

KING, D. (1998). Mechanised Corn Milling in Roman Britain. Unpublished presentation to the Quern Study Group. Reading. February 1998.

Langdon, J. (1991). Water-Mills and Windmills in the West Midlands, 1086-1500. Economic History Review, 44.3: 424-444.

Langdon, J. (2004). Mills in the Medieval Economy. Oxford.

LoAder, E. (1999). Worked Stone. In: A.P. FitzPATRick, C.A. Butterworth and J. Grove, Prehistoric and Roman Sites in East Devon: The A30 Honiton to Exter Improvement DBFO Scheme, 1996-9, 2, RomanoBritish Sites, Wessex Archaeology Report, 16.

Messurier, B. le (1981 reprint). Crossing's Guide to Dartmoor. Newton Abbot.

Mills, S. (2007). W.S. Barron \& Son, Mill Engineers of Gloucester. Gloucestershire Society for Industrial Archaeology, 45-9.

Mullin, D. (1988). Some Millstone Quarry Locations in the Forest of Dean, 1. The New Regard, 4: 53-9.

Natural England 2009. England's Geology by County. http://www.naturalengland.org.uk/ourwork/ conservation/geodiversiety/englands/counties, accessed 22 May, 2009.

Nowakowski, J.A, Quinnell, H., Sturgess, J., Thomas, C. And Thorpe, C. (2007). Return to Gwithian: Shifting the Sands of Time. Cornish Archaeology, 46: 13-76.
Ordnance Survey 1957: Geological Map of the British Islands. Chessington.

Peacock, D.P.S. (1980). The Roman Millstone Trade: A Petrological Sketch. World Archaeology, 12.1: 43-53.

Pitt-Rivers, A. (1884). Report on Excavations in the Pen Pits, near Penselwood, Somerset. London.

Pollard, S. (1974). A Late Iron Age Settlement and a Romano-British Villa at Holcombe, near Uplyme, Devon. Proceedings of the Devon Archaeological Society, 32: 59-161.

Quinnell, H. (1993). A Sense of Identity: Distinctive Cornish Stone-Artefacts in the Roman and PostRoman periods. Cornish Archaeology, 32: 29-45.

Quinnell, H. (1998-99). The Artefacts. In: D.A. Johnston , C. Moore and P. FAsham. Excavations at Penhale Round, Fraddon, Cornwall, 1995/1996. Cornish Archaeology, 37-38: 85-93.

QuinNell, H. (2004). Trethurgy: Excavations at Trethurgy Round, St. Austell. Community and Status in Roman and Post-Roman Cornwall. Truro.

QuinNELl, H. AND WatTs, S. (2004). Rotary Querns. In: H. QuinNell. Trethurgy: Excavations at Trethurgy Round, St. Austell. Community and Status in Roman and Post-Roman Cornwall. Truro: 145-151.

Rahtz, P. (1979). The Saxon and Medieval Palaces at Cheddar. BAR British Series, 65. Oxford.

Rahtz, P. AND Greenfield, E. (1977). Excavations at Chew Valley Lake, Somerset. London.

Ratcliffe, J. (1991). Lighting up the Past in Scilly. Truro.

Rawlings, M. (1995). Archaeological Sites along the Wiltshire Section of the Codford-Ilchester Water Pipeline. The Wiltshire Archaeological and Natural History Magazine, 88: 24-49.

Robinson, R. (1981). Millstone Working on Brent Moor. Devon and Cornwall Notes and Queries, 34.8: 333-34.

Roe, F. (1995). Stone. In J. Coles and S. Minnitt. Industrious and Fairly Civilized. The Glastonbury Lake Village. Taunton, 161-67.

Roe, F.E.S. (2000). Worked Stone. In: J.C. Barrett, P.W.M. FreEman and A. Woodward. Cadbury Castle Somerset: The Later Prehistoric and Early Historic Archaeology, London. English Heritage Archaeological Report, 20: 262-69.

Roe, F. (2001). Querns and Millstone. In: P. LEACH. Excavation of a Romano-British Roadside Settlement in Somerset: Fosse Lane. Shepton Mallet. London. Britannia Monograph, 18: 235. 
Scrivens, S. (1976). Copy of a letter to Wells Museum in the collection of $\mathrm{M}$. Watts.

Shaffrey, R. (2006). Grinding and Milling: A Study of Romano-British Rotary Querns and Millstones made from Old Red Sandstone. BAR British Series, 409. Oxford.

Sмiтh, D. (1974). Quernstones. In G. Beresford, The Medieval Manor of Penhallam, Jacobstow, Cornwall. Medieval Archaeology, 18: 143-145.

Smyth, J. (1608). Men and Armour in Gloucestershire. http:www.coaley.net/glos1608/index.php, accessed 4 August 2014.

STANIER, P. (2000). Stone Quarry Landscapes: The Industrial Archaeology of Quarrying. Stroud.

TAngye, M. (1992). Decorated Mill-Stones. Old Cornwall, 11.2: 66-69.

TAYlor, R.J. (ed.) (1997). Mawgan Porth: A Settlement of the Late Saxon Period on the North Cornish Coast. English Heritage Archaeological Report, 13.

Thorold Rogers, J.E. (1866). A History of Agriculture and Prices in England, 1. Oxford.

Thorpe, J. (ed.) (1989). North Devon Watermills. Barnstaple.

Tucker, D.G. (1971). Millstone Making at Pennallt, Monmouthshire. Industrial Archaeology, 8: 229-39.
Tucker, D.G. (1973). Millstone Making in Gloucestershire. Gloucestershire Society of Industrial Archaeology Journal, 6-16.

VANCOUVER, C. (1808, reprinted 1969). General View of the Agriculture of the County of Devon. Newton Abbot.

WARD, O. (1982). Millstones from La Ferté-sousJouarre, France. Industrial Archaeology Review, 6.3: 205-10.

WARD, O. (1993). French Millstones. Notes on the Millstones Industry at La Ferté-sous-Jouarre. The International Molinological Society. Den Haag.

Watts, S. (2006). Rotary Querns c. 700-1700, Finds Research Group AD700-1700 Datasheet, 38.

Watts, S. (2014). Quernstones. In: C. SMart. A Roman Military Complex and Medieval Settlement on Church Hill, Calstock, Cornwall: Survey and Excavation 2007-2010. BAR British Series 603. Oxford: 83-5.

WatTs, S.R. (2014). The Life and Death of Querns: The Deposition and Use-Contexts of Querns in SouthWestern England from the Neolithic to the Iron Age. Southampton Monographs in Archaeology, New Series, 3.

Wilson, R.E. (1978). Water Mills in East Devo Devon and Cornwall Notes and Queries, 34.1: 34-6. 
